\title{
Efektifitas Zat Aktif Fipronil pada berbagai Substrat Fagostimulan untuk Pengendalian Kecoak Jerman (Blattella germanica $\mathbf{L}$.)
}

\author{
Riska Isna Maula, Hery Pratiknyo, Untung Susilo, Trisnowati Budi Ambarningrum \\ Fakultas Biologi, Universitas Jenderal Soedirman \\ Jalan dr. Suparno 63 Purwokerto 53122 \\ Email : riskaisna123@gmail.com
}

Rekam Jejak Artikel:

Diterima : 26/08/2019

Disetujui : 22/06/2020

\begin{abstract}
German cockroach (Blattella germanica L.), is a residential insect pest and vector of various diseases. To control its population, alternative chemical control models with Fipronil $0.03 \%$ are now being developed. Fipronil has been proven to be effective and has no resistance. To increase the effectiveness of the bait in controlling German cockroaches, a fipronil $0.03 \%$ combination needs to be developed with a phagostimulant bait of bananas, durian, erythisol sugar, and sugar formulation, so this study needs to be done. This study used an experimental method with a randomized block design (RBD), five treatments such as A: bait with a combination of banana phagostimulant and $0.03 \%$ fipronil, B: bait with a combination of durian phagostimulant and $0.03 \%$ fipronil, $\mathrm{C}$ : bait with a combination erythisol phagostimulant and $0.03 \%$ fipronil, D: bait with a combination of sugar phagostimulant and $0.03 \%$ fipronil, $\mathrm{K}$ : bait with a combination of matrix and fipronil $0.03 \%$ (control positive) was used for the interest test, and bait with a matrix without fipronil $0.03 \%$ (control negative) was used for mortality testing. The observations the average results for durian, banana, sugar formulated, erytrisol sugar and controls, respectively $20 \%, 20 \%, 21.6 \%, 12.4 \%$, and $22.8 \%$, while the results bait consumed with durian stimulation are $0.29 \mathrm{~g}$, banana $0.31 \mathrm{~g}$, sugar formulation $0.28 \mathrm{~g}$, erytrisol sugar $0.26 \mathrm{~g}$ and control $0.24 \mathrm{~g}$. However, based on statistical tests, the results of the interest test with the feed consumption test between treatments showed no significant difference ( $p>0.05)$. The test results in mortality of cockroaches Germany's feed with phagostimulan durian, banana, formulations sugar, sugar erytrisol and control consecutively $98 \% 100 \%, 98 \%, 98 \%$, and $20 \%$, based on the statistical test there is a significant difference ( $<<0.05)$, where the difference based on the Duncan test is their treatment compared to control. Keywords: Blattella germanica, Bait gel, Controlling, Phagostimulant
\end{abstract}

\begin{abstract}
Abstrak
Kecoak Jerman (Blattella germanica L.), adalah serangga pengganggu permukiman dan vektor berbagai macam penyakit. Dalam rangka pengendalian populasinya, saat ini mulai dikembangkan model alternatif pengendalian kimiawi umpan beracun dengan bahan aktif Fipronil 0,03\%. Guna meningkatkan efektifitas umpan dalam mengendalikan kecoak Jerman, perlu dikembangkan kombinasi fipronil $0.03 \%$ dengan umpan berfagostimulan pisang, durian, gula erythisol, dan formulasi gula, oleh karena itu kajian tentang hal ini perlu dilakukan. Penelitian ini menggunakan metode eksperimental dengan rancangan acak kelompok (RAK), lima perlakuan berupa perlakuan A: umpan dengan kombinasi fagostimulan pisang dan 0,03\% fipronil, B: umpan dengan kombinasi fagostimulan durian dan $0,03 \%$ fipronil, C: umpan dengan kombinasi fagostimulan gula erythisol dan $0,03 \%$ fipronil, D: umpan dengan kombinasi fagostimulan gula dan 0,03\% fipronil, $\mathrm{K}$ : umpan dengan kombinasi matriks dan fipronil $0,03 \%$ (kontrol positif) digunakan untuk uji ketertarikan, serta umpan dengan matriks tanpa fipronil $0,03 \%$ (kontrol negatif) digunakan untuk uji mortalitas. Hasil pengamatan pada uji ketertarikan memproleh hasil rata-rata untuk umpan berfagostimulan durian, pisang, formulasi gula, gula erytrisol dan kontrol berturut-turut yaitu 20\%, 20\%, 21,6\%, 12,4\% dan $22,8 \%$, sedangkan hasil pengamatan untuk bobot umpan yang dikonsumsi hasil rata-ratanya untuk umpan berfagostimulan durian $0.29 \mathrm{~g}$, pisang $0.31 \mathrm{~g}$, formulasi gula $0.28 \mathrm{~g}$, gula erytrisol $0.26 \mathrm{~g}$ dan kontrol $0.24 \mathrm{~g}$. Namun berdasarkan uji statistik hasil uji ketertarikan dengan uji konsumsi umpan antar perlakuan menunjukkan perbedaan tidak nyata $(p>0.05)$. Hasil uji mortalitas menunjukkan rata-rata kematian kecoak jerman untuk umpan dengan fagostimulan durian, pisang, formulasi gula, gula erytrisol dan kontrol berturut-turut yaitu $98 \%, 100 \%, 98 \%$, $98 \%$ dan $20 \%$, berdasarkan hasil uji statistik terdapat perbedaan yang nyata $(\mathrm{p}<0.05)$, dimana perbedaan bardasarkan uji Duncan terdapat diantara perlakuan dengan kontrol.

Kata kunci: Blattella germanica, fagostimulan, pengendalian, umpan gel
\end{abstract}

\section{PENDAHULUAN}

Kecoak Jerman (Blattella germanica L.), adalah serangga hama permukiman di berbagai tempat terutama lingkungan perkotaan. Kecoak
Jerman tidak hanya mampu mencemari makanan, namun juga merupakan vektor yang membawa dan menularkan berbagai agen patogen yang menimbulkan berbagai macam penyakit, 
menyebabkan reaksi alergi dan tekanan psikologis bagi manusia (Mahmoud et al., 2013). Kecoak Jerman mampu beradaptasi dengan lingkungan manusia, bertahan hidup pada berbagai kondisi lingkungan, baik di luar maupun di dalam ruangan, namun lebih menyukai tempat-tempat yang kotor terutama bangunan dengan kondisi sanitasi yang buruk. Saat ini, Kecoak Jerman merupakan serangga hama internasional yang penting untuk dikendalikan (Madona et al., 2015).

Pengendalian kecoak Jerman yang dilakukan masyarakat pada saat ini, masih banyak menggunakan cara kimiawi, seperti penggunaan insektisida aerosol misalnya penyemprotan dan pengkabutan karena dinilai lebih praktis walaupun, kenyataannya penggunaan insektisida aerosol banyak meninggalkan residu yang berbahaya bagi kesehatan manusia, menyebabkan keracunan, kerusakan ekosistem dan pencemaran lingkungan. Bahan-bahan yang biasanya digunakan sebagai insektisida semprot yaitu propoksur, resmetrin dan piretrin (Raini, 2009). Pengendalian kecoak dapat dilakukan dengan berbagai cara, yaitu secara sanitasi, biologis, dan mekanik. Pengendalian secara biologis yaitu dengan pemanfaatan makhluk hidup untuk mengendalikan kecoak Jerman, pengendalian secara mekanik dilakukan secara langsung dengan menggunakan tangan maupun dengan bantuan alat dan mesin, sedangkan pengendalian secara sanitasi merupakan teknik pembersihan dalam hal ini yaitu membersihkan bagian-bagian yang sekiranya menjadi tempat persembunyian kecoak Jerman (Environmental Health Watch, 2005).

Pengendalian kecoak jerman memerlukan metode alternatif lain yang lebih aman dan efektif bagi manusia dan lingkungan, salah satunya menggunakan formulasi umpan beracun (baiting poison). Umpan beracun adalah campuran dari insektisida atau senyawa kimia dalam makanan dan minuman yang dikombinasikan untuk memikat kecoak agar datang dan memakan umpan tersebut (Arifah et al., 2016). Umpan beracun (gel baits) telah menjadi metode utama dalam mengendalikan kecoak jerman di Amerika Serikat. Bahan aktif yang digunakan dalam pembuatan umpan beracun yaitu hydramethylnon, fipronil, abamectin dan imidacloprid. Umpan ini terbukti aman dan sangat efektif untuk digunakan. Umpan juga lebih aman dan lebih ramah lingkungan dari pada insektisida yang aplikasinya langsung mengenai target. Ketika bahan aktif dimasukan kedalam umpan, kecoak akan dengan mudah mengkonsumsi dosis letal hanya dari makanan tersebut. Oleh karena itu, umpan dianggap lebih kecil kemungkinannya menyebabkan resistensi tingkat tinggi dari pada insektisida dan infiltrasi lainnya (Wang et al., 2004).

Bahan aktif fipronil dapat digunakan sebagai alternatif yang dapat mengendalikan kecoak di Indonesia (Connelly, 2001). Fipronil bersifat nonrepellen terhadap serangga dan mampu menyebabkan secondary kill pada kecoak yang memakan kotoran kecoak yang telah mengandung fipronil, sehingga fipronil merupakan insektisida yang banyak diformulasikan ke dalam bentuk umpan untuk pengendalian kecoak jerman (Sigit et al., 2006). Langkah awal yang harus dilakukan dalam pembuatan formulasi umpan beracun, yaitu mencari kombinasi umpan yang paling disukai oleh kecoak. Setiap jenis kecoak memiliki kesukaan terhadap umpan yang berbeda (Cooper \& Schal, 1992). Kecoak lebih menyukai makanan yang mengandung gula, protein, dan kadar air yang tinggi, serta makanan yang memiliki bau yang menyengat seperti hasil fermentasi (Winarno, 2001).

Menurut Ahmad \& Suliyat (2011), kombinasi fruktosa dan 4 fagostimulan yaitu pisang, feses kecoak, hati ayam dan darah sapi dalam umpan gel yang mengandung $44 \%$ air, memberikan kombinasi formulasi yang sangat baik dan sangat menarik bagi kecoak. Buah pisang dan hati ayam merupakan fagostimulan yang paling baik dalam menarik kecoak Jerman. Lauprasert et al. (2006) menyatakan bahwa fagostimulan pisang menunjukkan hasil signifikan disukai kecoak Jerman jantan dan betina, karena kaya kandungan karbohidrat. Gula sangat baik digunakan sebagai fagostimulan. Gore \& Schal (2004), menyatakan larutan yang mengandung air, asam borat dan campuran gula termasuk fruktosa, glukosa, maltosa dan sukrosa sebagai fagostimulan, efektif dan cepat membunuh kecoak Jerman. Fagostimulan yang lain yang digunakan yaitu buah durian. Sholehah \& Djunaedy (2015), menyatakan bahwa ekstrak kulit buah durian memberikan kematian pada rayap sampai 94,7\%. Hal tersebut, dikarenakan kandungan zat metabolit sekunder yang terkandung dalam kulit buah durian. Tanga et al. (2017), menyatakan bahwa erytrisol dengan kandungan gula alkohol dan $75 \%$ sukrosa, mampu mengendalikan lalat Drosophila suzukii.

Umpan komersial berbahan aktif fipronil sudah digunakan sejak tahun 1990an (Silverman \& Bieman,1993). Penggunaan fipronil sebagai campuran umpan sebelumnya telah di lakukan oleh Ahmad dan Suliyat (2011) dalam penelitiannya, menggunakan kombinasi fagostimulan yaitu hati ayam, darah sapi, feses kecoak dan pisang menunjukkan tingkat kesukaan dan mortalitas yang berbeda-beda terhadap kecoak Jerman. Maka dari itu, perlu dilakukan penelitian untuk mengetahui apakah umpan dengan kombinasi fipronil 0,03\% dengan substrat fagostimulan yang berbeda dari penelitian sebelumnya yaitu menggunakan pisang, durian, erythrisol dan kombinasi gula efektif dalam mengendaliakan kecoak Jerman. Namun, sampai sekarang insektisida formulasi semprot dari golongan piretroid menjadi pilihan yang paling banyak digunakan untuk mengendalikan kecoak Jerman. Maka dari itu, perlu adanya alternatif pengendalian kecoak Jerman menggunakan metode kimia yang lebih aman dan efektif bagi manusia dan 
lingkungan, salah satunya yaitu menggunakan formulasi umpan beracun (baiting poison). Tujuan penelitian ini adalah mengetahui daya tarik, konsumsi, dan mortalitas kecoak Jerman terhadap umpan beracun (feeding indeks) dengan fagostimulan berbeda. Hasil penelitian ini diharapkan dapat memberikan informasi mengenai bahan-bahan yang paling efektif digunakan sebagai fagostimulan umpan gel untuk mengendalikan kecoak Jerman dan memberikan informasi mengenai rata-rata konsumsi per individu kecoak Jerman terhadap umpan gel yang diformulasikan dari setiap bahan yang dicobakan.

\section{MATERI DAN METODE}

\section{Pemeliharaan Kecoak Jerman}

Pemeliharaan kecoak Jerman di lakukan berdasarkan metode Ahmad dan Suliyat (2011) pada wadah plastik berdiameter $32 \mathrm{~cm}$ (Gambar 1). Upaya dalam mencegah lari, pada mulut toples diolesi campuran vaselin dan minyak. Pemberian makan dan minum di lakukan setiap 1 minggu sekali secara ad libitum. Pakan yang diberikan selama pemeliharaan adalah makanan kucing (merk Essensial).

\section{Pembuatan Umpan Gel}

Umpan gel dibuat dengan cara yaitu agar dan air di masak sampai mendidih, setelah mendidih kemudian didiamkan \pm 5 menit. Bahan tersebut kemudian dicampurkan dengan bahan pakan. Bahan-bahan yang sudah dicampur dengan bahan pakan lainnya kemudian dituang ke dalam mixer dan diaduk dengan kecepatan sedang sampai semua komponen terlarut. Setelah halus, dimasukan ke dalam wadah kemudian didiamkan. Matriks, fagostimulan dan fipronil $0,03 \%$ kemudian diaduk sampai semua komponen tercampur, tahapan ini mengacu pada penelitian Ahmad \& Suliyat, (2011). Resep ini dimodifikasi sesuai dengan fagostimulan yang sudah ditentukan yaitu, gula erytrisol, durian, pisang, formulasi gula dan kontrol. Umpan yang telah dibuat kemudian didinginkan dalam lemari es pada suhu $4^{0} \mathrm{C}$ dan umpan siap untuk digunakan.

\section{Uji Efektifitas Umpan}

Uji ini dilakukan sebanyak tiga tahap. Tahap yang petama yaitu uji pilihan (choice) digunakan untuk menguji ketertarikan kecoak, tahap ke dua adalah uji paksa (not choice) yaitu digunakan untuk uji mortalitas kecoak jerman, sedangkan uji ketiga yaitu perhitungan bobot umpan yang dikonsumsi. Penelitian ini menggunakan metode eksperimental dengan rancang acak kelompok (RAK). Perlakuan yang digunakan antara lain (P) umpan kombinasi fagostimulan pisang dengan zat aktif prifonil $0,03 \%$, (D) umpan kombinasi fagostimulan durian dengan zat aktif prifonil 0,03\%, (GE) umpan kombinasi fagostimulan erytrisol dengan zat aktif prifonil $0,03 \%$ (FG) umpan kombinsi fagostimulan formulasi gula (maltosa, sukrosa dan glukosa) dengan perbandingan $3: 2: 1$ dengan zat aktif prifonil $0,03 \% \quad$ (F) umpan dengan kombinasi matriks dan fipronil $0,03 \%$ (kontrol negatif) digunakan untuk uji ketertarikan, serta (K) umpan dengan matriks tanpa fipronil $0,03 \%$ (kontrol positif). Jumlah hewan uji yang digunakan berjumlah 250 ekor. Pemberian umpan beracun dilakukan dengan metode umpan (feeding method) yang diletakkan dalam suatu arena uji. Parameter yang diukur untuk efektifitas umpan yaitu kehadiran yang merupakan Jumlah individu kecoak Jerman yang mendatangi setiap umpan dengan fagostimulan berbeda, mortalitas kecoak (kematian kecoak) yang mengkonsumsi umpan gel beracun, dan konsumsi umpan (feeding index).

\section{Prosedur uji pilih (choice) (Amalia \& Harahap, 2010)}

Kecoak jerman jantan strain VCRU sebelum digunakan sebagai hewan uji terlebih dahulu dipuasakan selama 1 x 24 jam. Dilakukan aklimasi kecoak jerman jantan sebanyak 50 ekor yang dimasukan ke dalam arena uji 5 chamber selama \pm 30 menit. Umpan sebanyak $1 \mathrm{~g}$ diletakan di masing-masing chamber. Kecoak dibiarkan untuk memilih umpan yang paling di senangi. Data uji ini digunakan untuk mengetahui kehadiran kecoak jerman pada masing-masing umpan. Pengamatan dilakukan selama 180 menit/3 jam dengan waktu pengamatan 15, 30, 60, 120, dan 180 menit. Perlakuan diulang sebanyak 5 kali ulangan.

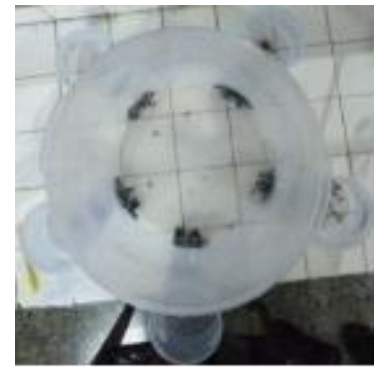

Gambar 1. Arena Uji Ketertarikan Kecoak Jerman terhadap UmpanProsedur uji paksa (not choice) sebagai berikut (Ahmad \& Suliyat, 2011 dimodifikasi)

Kecoak jerman jantan strain VCRU yang telah dipuasakan selama 1 x 24 jam masing-masing berjumlah 10 ekor dimasukan ke dalam toples plastik berdiameter $15 \mathrm{~cm}$ untuk setiap pelakuan. Sebelum perlakuan dilakukan aklimatisasi kecoak Jerman \pm 30 menit. Umpan sebanyak $1 \mathrm{~g}$ dimasukan kedalam arena. Jumlah ulangan sebanyak 5 kali untuk setiap perlakuan. Perhitungan efektifitas umpan dilakukan selama 12 jam dengan waktu pengamatan setiap 1, 3, 6 dan 12 jam. Data kematian merupakan parameter efektifitas. Setiap pengamatan di lakukan pencatatan jumlah kecoak yang mati (Gambar 2.). 


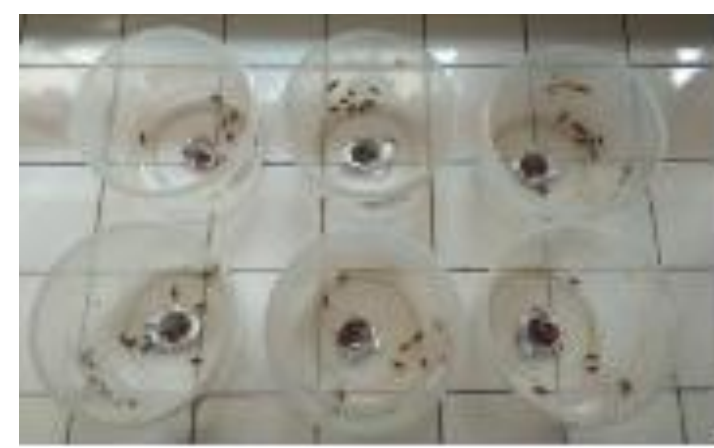

Gambar 2. Arena Uji mortalitas kecoak Jerman.

\section{Prosedur perhitungan bobot umpan yang dikonsumsi (feeding indeks)}

Bobot awal umpan yang diberikan ditimbang kemudian pakan sisa ditimbang. Hasil dari konsumsi umpan kemudian digunakan untuk menghitung feeding indeks menggunakan rumus:

$\mathrm{FI}=\frac{\text { Pakan perlakuan yang dikonsumsi }(g) \text {-pakan kontrol }(g)}{\text { Pakan perlakuan yang dikonsumsi }(g)+\text { pakan kontrol }(g)}$

Keterangan :

FI = Feeding index index (Silverman \& Ross, 1994).

\section{Analisis Data}

Analisis data untuk daya tarik, umpan yang dikonsumsi dan mortalitas dilakukan dengan menggunakan ANOVA (analysis of variance). Apabila hasil menunjukkan beda nyata antar perlakuan, maka di lakukan uji lanjut menggunakan uji Duncan pada $\mathrm{p}<0.05$, menggunakan softwere SPSS.

\section{HASIL DAN PEMBAHASAN}

\section{Uji Ketertarikan}

Hasil penelitian menunjukkan adanya kecenderungan perbedaan ketertarikan kecoak jerman terhadap masing-masing umpan. Umpan yang paling banyak dikunjungi oleh kecoak jerman adalah kontrol dengan rata-rata 22,8\% diikuti umpan dengan phagostimulan formulasi gula dengan ratarata kunjungan $21,6 \%$, serta umpan dengan phagostimulan durian dan pisang masing-masing dengan rata-rata $20 \%$. Sedangkan umpan yang paling sedikit dikunjungi oleh kecoak jerman adalah umpan dengan phagostimulan gula erytrisol dengan rata-rata kunjungan 12,4\% (Gambar 3).

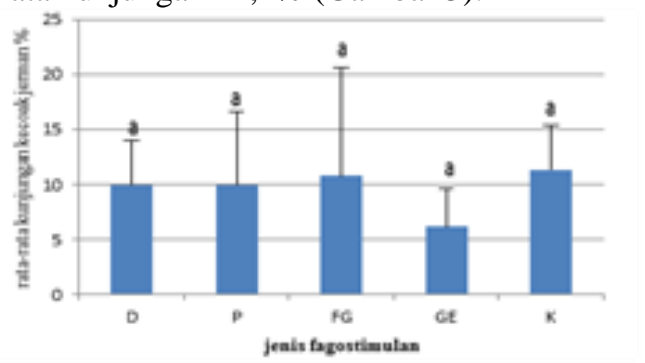

Gambar 3. Rata-rata Frekuensi Kujungan Kecoak Jerman Terhadap Umpan

Keterangan : Huruf yang sama menunjukkan tidak berbeda nyata secara statistik. $\mathrm{D}=$ durian $\mathrm{P}=$ pisang $\mathrm{FG}=$ formulasi gula, $\mathrm{GE}=$ gula erytrisol, $\mathrm{K}=$ kontrol

Hasil uji secara statistik menunjukkan tidak terdapat perbedaan yang signifikan $(p>0,05)$, diantara kunjungan kecoak jerman terhadap masingmasing umpan. Hal ini kemungkinan disebabkan oleh perilaku kecoak Jerman yang pada umumnya akan bergerak secara random dalam memilih makanan pada saat didedahkan pertama kali. Kecoak Jerman akan memilih semua makanan yang tersedia di sekitarnya karena kecoak merupakan serangga yang bersifat omnivora (Jensen et al., 2017). Perilaku ini disusul dengan mencicipi makanan, jika merasa tidak cocok maka kecoak akan meninggalkannya dan mencari makan lain yang sesuai palatabilitasnya. Menurut Ko et al. (2016), konsumsi kecoak jerman terhadap umpan sangat dipengaruhi oleh olfaktori (ketertarikan akan bau) dan gustatori (ketrtarikan karena palatabilitas). Olfaktori berperan dalam mendeteksi adanya makanan dengan cara membaui fagostimulan yang terkandung dalam makanan, dalam hal ini organ yang berperan yaitu antenna sedangkan gustatory berperan memilih umpan yang disukai dengan cara mencicipi makanan tersebut. Menurut Lauprasert et al. (2006), perilaku makan kecoak dimulai dengan meninggalkan tempat persembunyiannya dan kemudian dengan menggerakkan antena mereka untuk mendeteksi adanya bau makanan. Kecoak akan berjalan menuju makanan dan menyentuhnya, jika mereka merasa makanan tersebut sesuai dengan palatabilitasnya maka kecoak akan mulai makan dan minum. Namun jika makanan tersebut tidak memenuhi selera palatabiltas nutrisinya maka kecoak akan menghentikan makannya dan mencari makan lain yang memenuhi palatabilitas nutrisinya. Pada tahap orientasi kebutuhan nutrisinya kecoak jerman lebih menyukai makanan dengan kandungan karbohidrat yang tinggi dibandingkan dengan makanan dengan kandungan lemaknya tinggi. Menurut Lauprasert et al. (2006) kecoak akan mencicipi setiap umpan disusul kemudian mereka memilih umpan yang paling disukai.

Hal yang diduga mempengaruhi hasil tersebut yaitu bau yang ditimbulkan umpan yang sama-sama menyengat, menyebabkan kecoak jerman mudah mendeteksi adanya umpan, sehingga kecoak akan mencicipi semua jenis umpan yang tersedia kemudian akan memilih salah satu umpan yang sesuai dengan kebutuhan nutrisinya. Hal ini sesuai Lauprasert et al. (2006) yang menyebutkan bahwa, perilaku kecoak Jerman dalam memilih makan dimulai dari mendeteksi aroma makanan. Selain bau, tekstur makanan juga sangat mempengaruhi ketertarikan kecoak jerman terhadap makanan, dimana kecoak jerman cenderung lebih menyukai makanan dengan kandungan air yang lebih banyak 
dan makanan dengan tekstur yang lembek. Menurut Putra (2018), selain kandungan nutrisinya, tekstur umpan juga mempengaruhi kecoak jerman dalam memilih umpan. Kemungkinan lain adalah sifat kecoak yang tertarik pada warna terang pada umpan makanan, sedangkan pada penelitian ini warna umpan makanan yang diujikan relatif sama yaitu kecoklatan berbeda pada umpan makanan kontrol yang memiliki warna yang lebih terang. Hal ini sesuai penelitian sebelumnya dalam pengendalian serangga hama banyak menggunakan perangkap yang berwarna mencolok. Seperti yang dilakukan oleh Idris et al. (2012), menggunakan yellow sticky trap untuk pengendalian Bemisia tabaci.

Ketertarikan kecoak Jerman mendatangi umpan makanan mengandung formulasi gula pada penelitian ini, diduga kandungan gula yang tinggi memiliki daya tarik bagi kecoak jerman. Sebab gula merupakan sumber energi utama bagi kecoak jerman baik jantan maupun betina. Kecoak pada kondisi kelaparan, umumnya akan mencari sumber energi yang mudah diserap yang penting bagi kelangsungan hidupnya, seperti glukosa, maltosa, fruktosa dan sukrosa (Lauprasert et al., 2006; Nojima et al., 1999). Penelitian Lauprasert et al. (2006), menyebutkan bahwa kecoak Jerman menyukai makanan dengan kandungan gula tinggi terutama pada kecoak jerman betina. Hal Ini, karena kecoak Jerman betina membutuhkan banyak energi dan nutrisi untuk produksi ootekanya, sedangkan kecoak jerman jantan secara genetis lebih menyukai makanan yang banyak mengandung karbohidrat dan gula dibandingkan dengan lemak dan protein. Namun pada penelitian ini formulasi gula tidak menunjukkan perbedaan yang nyata terhadap ketertarikan kecoak Jerman dalam mendatangi umpan makanan $(\mathrm{P} \geq 0,05)$. Hal ini diduga umpan makanan dengan kandungan gula erytrisol memberikan efek fisiologis yang kurang menguntungkan bagi kecoak Jerman. Meskipun belum ada penelitian secara khusus pada kecoak Jerman, namun efek umpan dengan kandungan gula erytrisol ini pada lalat buah dikabarkan berefek toksik. Menurut O'Donnell et al. (2016), uji di laboratorium dengan menggunakan gula erythisol yang diberikan kepada Drosophila melanogaster mengurangi umur lalat dan koordinasi motoriknya. Hal ini berkaitan dengan efek insektisida yang dimiliki oleh erythisol jika serangga hama mengkonsumsinya.

\section{Bobot Umpan yang Dikonsumsi}

Hasil perhitungan bobot umpan yang dikonsumsi menunjukkan bahwa, rata-rata umpan yang dikonsumsi oleh kecoak jerman yaitu $0.24 \pm 0.121 \mathrm{~g}$ umpan kontrol, $0.29 \pm 0.095 \mathrm{~g}$ umpan dengan faagostimulan durian, $0.31 \pm 0.101 \mathrm{~g}$ umpan dengan fagostimulan pisang, $0.28 \pm 0.144 \mathrm{~g}$ umpan dengan fagostimulan formulasi gula dan
$0.26 \pm 0.123 \mathrm{~g}$ umpan dengan fagostimulan gula erytrisol (Gambar 4).

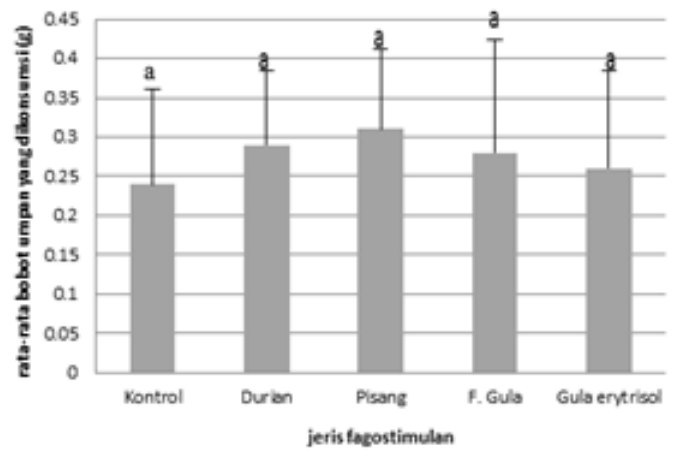

Gambar 4. Rata-rata Bobot Umpan yang dikonsumsi oleh Kecoak Jerman

Keterangan : Huruf yang sama menunjukkan tidak berbeda nyata secara statistik.

Perhitungan feeding index menunjukkan hasil yang relatif tidak berbeda antara umpan berfagostimulan pisang dengan durian yaitu masingmasing 0.1 dan 0.09 dan umpan dengan fagostimulan formulasi gula dan gula erytrisol masing-masing 0.05 dan 0.02 (Gambar 5).

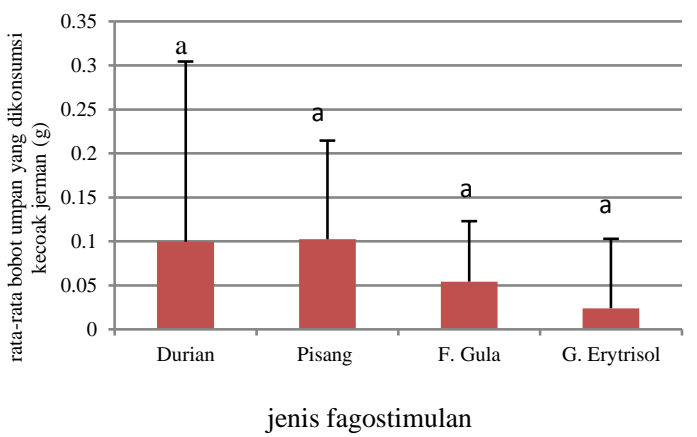

Gambar 5. Rata-rata Bobot Umpan yang Dikonsumsi Kecoak Jerman yang Dihitung Menggunakan Rumus Feeding Index

Keterangan :Huruf yang sama menunjukkan tidak berbeda nyata secara statistik.

Secara statistik hasil ini memperlihatkan bahwa rata-rata bobot umpan yang dikonsumsi oleh kecoak jerman menunjukkan perbedaan tidak signifikan ( $>0.05)$. pada penelitian ini menggunakan umpan dengan fagostimulan durian dan pisang yang memiliki bau yang sama-sama menyengat diduga menjadi kompetitor pilihan bagi kecoak Jerman Selain hal tersebut di atas, kemungkinan kecenderungan perilaku kecoak memilih makan yang terdekat dari tempat persembunyiaannya dan akan mencicipi semua makanan yang ditemuinya. Lauprasert et al. (2006) menyebutkan bahwa, perilaku kecoak Jerman dalam memilih makan dimulai dari mendeteksi aroma makanan dengan menggunakan antenanya, 
kemudian mendekati makanan secara perlahan dan memulai untuk menyentuh makanan tersebut yang kemudian dikonsumsi.

Hal menarik pada penelitian ini adalah tidak semua umpan yang dikunjung selalu menjadi pilihan utama dalam konsumsinya. Kecoak akan pindah pada makanan yang lain apabila dirasa makanan tersebut tidak sesuai dengan kebutuhannya untuk pertumbuhan. Hal ini sesuai dengan Putra (2018), yang menyatakan bahwa, walaupun frekuensi kunjungan tertinggi, belum tentu konsumsi pakan kecoak juga tinggi.

\section{Uji mortalitas}

Uji rata-rata mortalitas kecoak jerman terhadap umpan menunjukkan hasil yang berbeda antara masing-masing umpan, dengan rata-rata $20 \%$ pada kontrol, $98 \%$ pada umpan dengan fagostimulan formulasi gula, durian dan gula erytrisol serta $100 \%$ pada umpan fipronil dan umpan dengan fagostimulan pisang (Gambar 6).

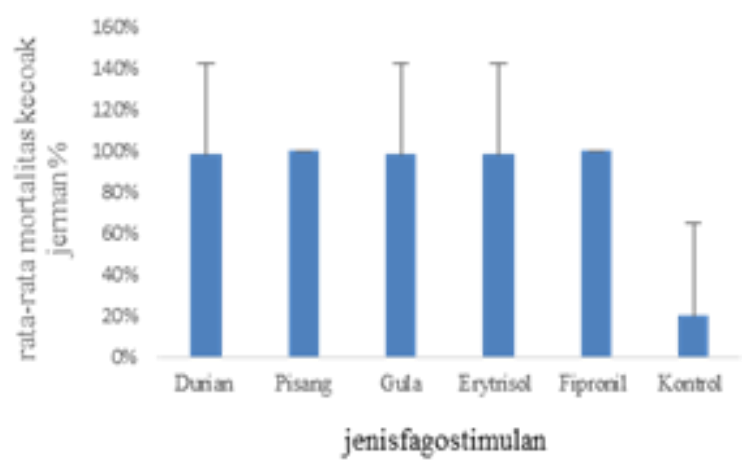

Gambar 6. Rata-rata Mortalitas Kecoak Jerman Terhadap Umpan

Keterangan : Huruf yang sama menunjukkan tidak berbeda nyata secara statistik.

Hasil uji statistik menunjukkan bahwa data mortalitas kecoak jerman terhadap masing-masing umpan berbeda signifikan $(\mathrm{p}<0.05)$. Hal ini mengindikasikan bahwa zat aktif fipronil memberikan efek membunuh yang menyebabkan mortalitas kecoak jerman. Hal ini, sesuai hasil penelitian Nasirian et al. (2006), yang melaporkan bahwa fipronil sangat efektif dalam mengendalikan kecoak jerman di lapangan. Ahmad dan Suliyat (2011), juga melaporkan bahwa hasil penelitian yang dilakukan menggunakan aplikasi umpan dengan zat aktif fipronil $0.03 \%$, sangat efektif dalam mengendalikan kecoak jerman.

Setelah diketahui adanya pengaruh yang signifikan perlakuan umpan terhadap mortalitas kecoak jerman, hasil data yang diperoleh diuji lanjut dengan uji lanjut Duncan, untuk mengetahui umpan mana yang paling berpengaruh (Tabel 1).
Tabel 1. Hasil Uji Lanjut Duncan Pengaruh Umpan terhadap Mortalitas Kecoak Jerman Terhadap Umpan Yang Berbeda

\begin{tabular}{cc}
\hline Perlakuan & Mortalitas \% \\
\hline Kontrol & $20^{\mathrm{a}}$ \\
Durian & $98^{\mathrm{b}}$ \\
formulasi gula & $98^{\mathrm{b}}$ \\
gula erytrisol & $98^{\mathrm{b}}$ \\
Pisang & $100^{\mathrm{b}}$ \\
Fipronil & $100^{\mathrm{b}}$
\end{tabular}

Keterangan : huruf yang sama menunjukkan tidak berbeda nyata secara statistik dengan uji lanjut Duncan.

Hasil uji lanjut Duncan (Tabel 1), menunjukkan bahwa pengaruh umpan yang mengandung zat aktif fipronil terhadap mortalitas kecoak jerman menunjukkan perbedaan dibanding kontrol. Umpan dengan fagostimulan yang mengandung zat aktif fipronil dan umpan kontrol positif (fipronil) memiliki rata-rata mortalitas $98 \%$ $100 \%$, sedangkan nilai rata-rata mortalitas terendah yaitu $20 \%$, terdapat pada umpan kontrol negatif (tanpa zat aktif fipronil). Hal ini, sesuai dengan penelitian yang dilakukan oleh Ahmad dan Suliyat (2011), yang menyatakan bahwa umpan dengan komponen gel, air, fruktosa, madu pisang, dan fipronil $0.03 \%$, bekerja sangat baik dan nyata dalam mengendalikan (membunuh) kecoak jerman. Ahmad dan Suliyat (2011), dalam penelitiannya juga menunjukkan umpan dengan komposisi matriks tanpa fipronil dan fagostimulan tidak memberikan kematian pada kecoak jerman.

Fipronil merupakan insektisida yang aksinya mengganggu fungsi normal saraf dengan cara memblok Gamma Aminobutyric Acid (GABA) gate chloride channel neuron pada sistem saraf pusat. Sistem GABA reseptor bertanggung jawab untuk mempertahankan aktivitas normal sistem saraf, misalnya stimulasi berlebih pada saraf. Fipronil mempengaruhi jenis targetnya dengan mengganjal saluran saluran klorida dari saraf, oleh karena itu potensi istirahat membran tidak bisa stabil yang mengakibatkan aktivitas neuronal berlebihan. Ketika sistem pencernakan serangga secara reguler diblok oleh fipronil, mengakibatkan eksitasi neural dan kematian pada serangga. Fipronil dapat membunuh serangga melalui kontak dan pencernaan (Connelly, 2001). Fipronil mempunyai toksisitas lebih tinggi terhadap serangga dibandingkan dengan mamalia, karena kemampuan melekat pada reseptor GABA pada kecoak 59 kali lebih kuat dibandingkan pada reseptor GABA pada tikus (Zhao et al., 2003).

Keseluruhan dari hasil penelitian mengenai penggunaan umpan dengan bahan aktif fipronil $0.03 \%$, efektif dalam mengendalikan kecoak jerman. Terutama penggunaan umpan dengan fagostimulan pisang yang mengandung $0.03 \%$ fipronil 
menunjukkan umpan ini sangat efektif untuk mengendalikan kecoak jerman, karena memberikan persentase kematian kecoak jerman $100 \%$ pada jam ke-6 setelah perlakuan. Fipronil memiliki sifat nonrepellen (tidak adanya daya tolak) bagi serangga dan tidak berbau, selain itu fipronil memiliki mode aksi yang berbeda dari insektisida golongan pyretroid. Fipronil berpotensi digunakan dalam manajemen pengendalian kecoak jerman yang telah resisten terhadap pyretroid. Menurut Lauprasert et al. (2006), fipronil sangat efektif dalam melawan kecoak jerman yang ada di lapangan. Fipronil berperan menjadi insektisida adalah bukti bahwa target utamanya yaitu serangga. Menurut Gunasekara et al. (2007) beberapa dosis mematikan fipronil untuk serangga adalah: 1,54, 0,43 dan 23,0 $\mu \mathrm{g} / \mathrm{L}$ untuk beberapa spesies nyamuk, $0,42 \mu \mathrm{g} / \mathrm{L}$ untuk pengusir hama dan untuk satu lebah adalah 46,2 ng. Sedangkan menurut WHO (2006), fipronil merupakan insektisida yang dapat digunakan sebagai bahan aktif pada umpan dengan konsentrasi antara $0,01 \%$ sampai dengan $0.05 \%$.

\section{SIMPULAN}

Berdasarkan hasil dan pembahasan di atas maka dapat disimpulkan bahwa ketertarikan kecoak Jerman pada umpan dengan berbagai fagostimulan yang dikombinasikan dengan zat aktif fipronil $0.03 \%$ tidak menunjukkan pengaruh yang nyata dalam waktu pengamatan 180 menit serta konsumsi umpan menunjukkan tidak ada perbedaan yang nyata antara konsumsi masing-masing umpan. Penggunaan fagostimulan tidak meningkatkan mortalitas kecoak jerman atau efektifitas zat aktif fipronil.

\section{DAFTAR REFERENSI}

Ahmad, I. \& Suliyat. 2011. Development of Fipronil Gel Bait Against German Cockroaches, Blattella germanica (Dictyoptera: Blattellidae): Laboratory and Field Performance in Bandung, Indonesia. Journal of Entomology, 8(3), pp. 288-294.

Amalia, H. \& Harahap, I. S. 2010. Preferensi Kecoa Amerika Periplaneta americana (L.) (Blattaria: Blattidae) terhadap Berbagai Kombinasi Umpan. J. Entomol. Indon, 7(2), pp. 67-77.

Arifah, F. G., Hestiningsih, R. \& Rahadian, R. 2016. Preferensi Kecoak Amerika Periplaneta americana (L.) (Blattaria : Blattidae) terhadap Baiting Gel. Jurnal Kesehatan Masyarakat (e-Journal), 4(4), pp. 289-297.

Cooper, R. A. \& Schal, C. 1992. Differential Development and Reproduction of the German Cockroach (Dictyoptera: Blattellidae) on Three Laboratory Diets. Journal of Economic Entomology, 85(3), pp. 838-844.
Connelly, P. 2001. Environmental Fate of Fipronil, Environmental Monitoring Branch,Department of Pesticide Regulation. California: California Environmental Protection Agency.

El-Sharabasy, H.M., Mahmoud, M.F., El-Bahrawy, A.F. \& El-Badry, Y.S. 2014. Food Preference of the German Cockroach, Blattella germanica (L.) (Dictyoptera: Blattellidae). Cercetări Agronomice $\hat{\imath}$ Moldova, XLVII (2).

Enviromental Health Watch. 2005. Factsheet Cockroach Control Guide. Enviromental Health Watch. Di akses pada tanggal 17 mei 2019.

Gore, J. C. \& Schal, C. 2004. Gene Expression and Tissue Distribution of the Major Human Allergen Bla g 1 in the German Cockroach, Blattella germanica L. (Dictyoptera: Blattellidae). Journal of Medical Entomology, 41(5), pp. 953-960.

Gunasekara, A.S., Truong, T., Goh, S.K., Spurlock, F. \& Tjeerdema, R.S. 2007. Environmental fate and toxicology of fipronil. Journal of Pesticide Science, 32(3), pp. 189-199.

Jensen, K., Katsumata, A.W., Schal, C., \& Silverman, J. 2017. Persistenceof a SugarRejecting Cockroach Genotype Under Various Dietary Regimes. Scientific Report, 7, pp. 1-10

Lauprasert, P., Sitthicharoenchai, D., Thirakhupt, K. \& Pradatsudarasar, A.O., 2006. Food Preference and Feeding Behavior of the German Cockroach, Blattella germanica (Linnaeus). J. Sci. Res. Chula. Univ., 31(2), pp. 121-126.

Madona, W. R., Rahayu, R., Dahelmi \& Hariani, N. 2015. Efektivitas Insektisida Komersial Terhadap Kecoak Jerman (Blattella Germanica L.) Strain VCRU-WHO, GFAJKT dan PLZ-PDG dengan Metode Kontak (Glass Jar). Jurnal Biologi Universitas Andalas (J. Bio. UA.), 4(2), pp. 113-118 .

Mahmoud, M.F., El-Bahrawy, A.F., El-Sharabasy, H.M. \& El-Badry,Y.S. 2013. Ecological Investigation, Density, Infestation Rate and Control Strategy of German Cockroach, Blattella germanica (L.) in Two Hospitals in Ismailia, Egypt. Arthropods, 2(4), pp. 216224.

Nojima, S., Nishida, R., \& Kuwahara, Y. 1999. Nuptial feeding stimulant: a male courtship pheromone of the German cockroach, Blattella germanica (L.) (Dictyoptera: Blattellidae). Naturwissenschaften 86, pp. 193-196.

Nasirian, H., Ladonni, H., \& Vatandoost, H. 2006. Duration of Fipronil Topical Application 
Toxicity in Blattella germanica Field Population Strains. Pakistan Journal of Biological Sciences, 9(5), pp. 800-804

O'Donnell, S., Baudier, K., \& Marenda, D.R. 2016. Non-nutritive polyol sweeteners differ in insecticidal activity when ingested by adult Drosophila melanogaster (Diptera: Drosophilidae). J. Insect Sci., pp. 16

Putra, A. H. 2018. Preferensi Pakan Beberapa Strain Kecoak Jerman, Blattella Germanica (Dictyoptera: Blattellidae). Jurnal Pendidikan Biologi dan Biosains, 1(1), pp. 714.

Raini, M. 2009. Toksisitas Insektisida Rumah Tangga dan Pencegahan Keracunan. Artikel. Media Penelitian dan Pengembangan Kesehatan. 19(2), pp. 1-9.

Sholehah, D. N. \& Djunaedy, A. 2015. Potensi Berbagai Limbah Pertanian Sebagai Anti Rayap. Agrovigor, 8(1), pp. 68-72.

Sigit, S. H., Koesharto, F., Hadi, U. K. \& Gunandini, D. J. 2006. Hama Permukiman Indonesia: Pengenalan, Biologi dan Pengendalian. Bogor: Unit Kajian Pengendalian Hama Permukiman, Fakultas Kedokteran Hewan, Isntitut Pertanian Bogor.

Silverman, J. \& Ross, M.H. 1994. Behavioral Resistance of Field-Collected German Cockroaches (Blattodea: Blattellidae) to Baits Containing Glucose. Physiological and Chemical Ecology, 23(2) : 425-430.
Silverman, J. \& Bieman, D.N. 1993. Glucose Aversion in the German Cockroach, Blattella germanica. J. Insect Physiol, 39(11), pp. 925933.

Tanga, S.B., Lee, J.C., Jung, J.K. \& Choi, M.Y. 2017. Effect of erythritol formulation on the mortality, fecundity and physiological excretion in Drosophila suzukii. Journal of Insect Physiology, 101, pp. 178-184.

Wang, C., Scharf, M.E. \& Bennett, G.W. 2004. Behavioral and Physiological Resistance of the German Cockroach to Gel Baits (Blattodea: Blattellidae). Journal of Economic Entomology, 97(6), pp. 20672072.

Winarno FG. 2001. Hama Gudang danTeknik Pemberantasannya.Bogor: M Brio Press.

World Health Organization. 2006. Pesticides and Their Application for Control of Vectors and Pest of Public Health Importance, sixth adition, Departemen of Control Neglected Tropical Disease WHO Pesticide evaluation scheme (WHOPES)

Zhao, X., Salgado, V.L., Yeh, J.Z., \& Narahashi, T. 2003. Differential Actions of Fipronil and Dieldrin Insecticides on GABA-gate Chloride Channels in Cockroach Neurons, JPET. 103.051839 